\title{
LARGE AMERICAN AVOCET CLUTCHES AT DOWLING LAKE, ALBERTA
}

\section{by Kees Vermeer, Canadian Wildlife Service, Edmonton}

On June 15, 1967 and on June 9, 1970 I visited a small bare sand reef in Dowling Lake $\left(51^{\circ} 44^{\prime} \mathrm{N} ; 112^{\circ} 00^{\prime}\right.$ W), which measured 0.15 acres in 1970. American Avocets (Recurvirostra americana) were nesting on the reef on both dates. The reef contained 17 and 13 Avocet nests in 1967 and 1970 respectively. In 1970 there was also one Piping Plover nest and six Common Tern nests. No Avocets were observed nesting on the reef during a visit in June, 1968. Their absence may possibly be explained by the fact that Dowling Lake was then almost completely dry, the reef being connected to the mainland by an extensive mud flat.

The distances between the rims of adjacent nests were measured to the nearest inch. The nesting distance ranged from $77^{\prime \prime}$ to $22^{\prime} 4^{\prime \prime}$, the mean distance being $11^{\prime} 5^{\prime \prime}$. The nesting density in 1970 was 13 nests/ 0.15 acres or 86.6 nests per acre.

As half of the 30 nests observed in 1967 and 1970 contained more than four eggs (Table 1), it is possible that those clutches were the result of more

Table 1. Clutch size of American Avocets at Dowling Lake, Alberta in 1967 and 1970.

\begin{tabular}{ccc}
\hline Clutch Size & \multicolumn{2}{c}{ Number of nests } \\
& 1967 & 1970 \\
\hline 1 & 1 & 1 \\
2 & 2 & $2^{*}$ \\
3 & 1 & 1 \\
4 & 4 & 3 \\
5 & 3 & 0 \\
6 & 1 & 1 \\
7 & 5 & 3 \\
8 & 0 & 2 \\
\hline Total & 17 & 13 \\
Mean clutch size & 4.71 & 4.85 \\
*One nest also contained two Com- &
\end{tabular}

than one female laying in the same nest. F. L. Farley reports (p. 34, Birds of the Battle River Region, Institute of Applied Arts Ltd., Edmonton, 1932) "On May 24th, 1924, I found a colony of these handsome waders nesting on a small island in Bittern Lake. The 'community spirit' idea was quite in evidence in the colony, as four nests only were serving the needs of eight pairs. Two of the nests contained eight eggs each, one held seven, while the fourth nest had six eggs. As four eggs is the usual number laid by these birds, it is evident that two pairs were making use of each nest."

E. Beapré reports (A. C. Bent, Life histories of North American shorebirds. U.S. Natl. Mus. Bull. 142, 1927, p. 39) that five pairs of Avocets, found by him on a small lake in southern Alberta, occupied three nests, one of which contained eight eggs, another seven and the third four.

\section{ERRATA}

I made some mistakes in my article "Great Blue Heron colonies in Saskatchewan in 1970" which was printed in the December, 1970, Blue Jay. The sentence on page 159 "Sixty percent of 15 colonies north of Saskatoon, $50^{\circ}$ $07^{\prime} \mathrm{N}$, were on lake islands as compared to only 19 percent of 16 colonies scuth of that city." should read: "Sixty three percent of 16 colonies north of Saskatoon, $52^{\circ} 07^{\prime} \mathrm{N}$, were on lake islands as compared to 13 percent of 15 colonies south of that city." The sentence on page 160: "Great Blue Herons nested together with Double-crested Cormorants in birches and aspen poplars at Kazon Lake", should read: "Great Blue Herons nested together with Double-crested Cormorants in birches and aspen poplars at Churchill Lake." One figure in Table 2, under "Total" reads " 12 ", but should read "13".-Kees Vermeer, Edmonton. 